\title{
Kreativitas Siswa Dalam Memecahkan Masalah Matematika Materi Pola Bilangan dengan Pendekatan Matematika Realistik (PMR)
}

\author{
Suherman \\ IAIN Raden Intan Lampung : suherman_alghifari@yahoo.co.id \\ Submitted : 11-03-2015, Revised : 24-04-2015, Accepted : 16-06-2015
}

\begin{abstract}
This research is qualitative descriptive. This study using the test method. Validity of the data in this study is done by increasing the persistence and triangulation of time. The data analysis techniques performed by data reduction is done by selecting the workmanship students. Reduction results that have been presented, then presented in the form of analysis. The results showed that: 1) To study the pattern of numbers more attractive and easier when using realistic mathematics approach. 2). Introducing realistic mathematics learning problems that are applicable in everyday life so that learning will be more meaningful. 3) Learning mathematics realistic emphasis on understanding the concept of planting, the creativity of students and poses reasoning in mathematics.
\end{abstract}

Keywords: Approach of Realistic Mathematics; Creativity; Problem Solving.

\begin{abstract}
Abstrak
Penelitian ini merupakan penelitian kualitatif deskriptif. Penelitian ini menggunakan metode tes. Validitas data dalam penelitian ini dilakukan dengan meningkatkan ketekunan dan triangulasi waktu. Adapun teknik analisis data dilakukan dengan reduksi data dilakukan dengan cara memilih hasil pengerjaan siswa. Hasil reduksi yang telah dipaparkan, kemudian dipaparkan dalam bentuk analisis. Hasil penelitian menunjukkan bahwa: 1) Mempelajari pola bilangan lebih menarik dan mudah jika menggunakan pendekatan matematika realistik. 2). Pembelajaran matematika realistik memperkenalkan masalah yang bersifat aplikatif dalam kehidupan sehari-hari sehingga pembelajaran akan lebih bermakna. 3) Pembelajaran matematika realistik menekankan pada penanaman konsep pemahaman, kreativitas siswa dan poses nalar dalam matematika.
\end{abstract}

Kata Kunci: Kreativitas; Pemecahan Masalah; Pendekatan Matematika Realistik.

\section{PENDAHULUAN}

Pandangan masyarakat tentang pelajaran matematika merupakan pelajaran yang sulit dan menakutkan adalah hal yang cukup beralasan. Yansen Marpaung (2003:1) mengungkapkan "pendidikan matematika kita selama ini tidak berhasil meningkatkan pemahaman matematika yang baik pada siswa, tetapi berhasil menumbuhkan perasaan takut, persepsi terhadap matematika sebagai ilmu yang sukar dikuasai, tidak bermakna, membosankan, menyebabkan stres pada diri siswa". Ungkapan tersebut mengindikasikan bahwa bagi sebagian besar siswa khususnya di Indonesia, pembelajaran matematika selama ini belum mampu mengubah ranah afektif dan kognitif sis wa menuju yang lebih baik.

Anggapan masyarakat luas tersebut berimplikasi pada rendahnya prestasi belajar matematika siswa dan hanya sebagian kecil siswa yang berhasil mencapai prestasi belajar 
tinggi, selebihnya siswa memiliki prestasi belajar yang belum memuaskan. Purwoto (1996:17) menyatakan bahwa matematika adalah pelajaran yang konsepnya tersusun secara hierarkis dari yang mudah atau sederhana meningkat ke yang sulit atau rumit. Dengan demikian, jika siswa belum dapat menguasai konsep yang mendasar maka siswa akan merasa kesulitan menguasai konsep yang lebih lanjut. Pada umumnya dalam mempelajari pelajaran yang dianggap sulit, siswa cenderung menunjukkan minat belajar dan motivasi berprestasi yang rendah pula. Padahal matematika seharusnya menjadi pelajaran yang menantang sehingga menarik minat belajar dan rasa ingin tahu yang besar bagi siswa. Hal ini memberikan kesan bahwa kualitas pendidikan matematika yang ada masih jauh dari harapan.

Fakta menyatakan berdasarkan kajian Programme for International Student Asssessment (PISA) 2003, yang dikutip oleh Sutarto Hadi dalam majalah PMRI (2007:3) mengemukakan sebanyak 50,5\% siswa Indonesia memiliki kemampuan keberaksaraan matematika di bawah level 1, yaitu hanya mampu menyelesaikan satu langkah soal matematika (pada situasi ini siswa bahkan tidak dapat menggunakan prosedur, rumus, dan algoritma sederhana untuk menyelesaikan soal matematika). Sebanyak $27,6 \%$ berada pada level 1, yaitu dapat menggunakan prosedur, rumus, dan alagoritma dasar, serta mampu melakukan penafsiran yang bersifat aksara dan penalaran yang bersifat langsung. Sebanyak 14,8\% berada pada level 2, yaitu mampu menerapkan pemecahan masalah sederhana, menafsirkan dan menyampaikannya. Sebanyak 5,5\% berada pada level 3, yaitu siswa dapat menyelesaikan persoalan secara efektif untuk situasi konkret dan dapat menyampaikan penjelasan dan argumentasi dengan baik. Hanya 1,4\% berada pada level selanjutnya.

Salah satu penyebab rendahnya kemampuan matematika siswa karena pembelajaran matematika yang sering dilakukan guru adalah model klasikal dengan metode ekspositori dan pendekatan mekanistik, yaitu algoritma aritmatika dan rumus matematika diinformasikan dan dilatihkan melalui tugas kepada siswa, dan diakhiri dengan melatihkan aplikasinya. Secara garis besar, situasi pembelajaran menggambarkan suatu kegiatan guru aktif memberikan informasi, sedangkan kegiatan siswa menyimak, mencatat, dan mengerjakan tugas.

Mengingat pentingnya kemampuan matematika bagi siswa dalam proses belajar selanjutnya maka masalah rendahnya hasil belajar matematika siswa dan sikap siswa terhadap matematika yang cenderung negatif perlu diupayakan pemecahannya. Salah satu pemecahan masalah ini yang akan dibahas dalam makalah ini adalah pendekatan matematika realistik.

Pendidikan Matematika Realistik (PMR) dikembangkan berdasarkan pemikiran Hans Freudenthal yang berpendapat bahwa matematika merupakan aktivitas insani (human activities) dan harus dikaitkan dengan realitas. Berdasarkan pemikiran tersebut, PMR mempunyai ciri antara lain: dalam proses pembelajaran siswa harus diberikan kesempatan untuk menemukan kembali (to reinvent) matematika melalui bimbingan guru (Gravemeijer 1994, dalam Hadi), dan penemuan kembali (reinvention) ide dan konsep matematika tersebut harus di mulai dari penjelajahan berbagai situasi dan persoalan "dunia riil" (De Lange 1995, dalam Hadi).

Dunia riil adalah segala sesuatu di luar matematika, dapat berupa mata pelajaran lain selain matematika, bidang ilmu yang berbeda dengan matematika, atau kehidupan seharihari dan lingkungan sekitar kita (Blum \& Niss 1989, dalam Hadi). Dunia riil diperlukan untuk 
mengembangkan situasi kontekstual dalam menyusun materi kurikulum. Materi kurikulum yang berisi rangkaian soal-soal kontekstual akan membantu proses pembelajaran yang bermakna bagi siswa. Dalam PMR, proses belajar mempunyai peranan penting. Rute belajar (learning route) di mana siswa mampu menemukan sendiri konsep dan ide matematika, harus dipetakan (Gravemeijer 1997, dalam Hadi). Sebagai konsekuensinya, guru harus mampu mengembangkan pengajaran yang interaktif dan memberikan kesempatan kepada siswa untuk memberikan kontribusi terhadap proses belajar mereka.

Salah satu konsep yang amat penting dalam bidang kreativitas adalah hubungan antara kreativitas dan aktualisasi diri. Menurut psikolog humanistik seperti Maslow dan Rogers, aktualisasi diri ialah apabila seseorang menggunakan semua bakat dan talentanya untuk menjadi apa yang ia mampu mengaktualisasikan atau mewujudkan potensinya. Pribadi yang dapat mengaktualisasikan dirinya adalah seseorang yang sehat mental, dapat menerima dirinya, selalu tumbuh, berfungsi sepenuhnya, berpikiran demokratis, dan sebagainya. Menurut Maslow (1968) dalam Utami Munandar (2004: 18) aktualisasi diri merupakan karakteristik yang fundamental, suatu potensialitas yang ada pada semua manusia saat dilahirkan, akan tetapi yang sering hilang, terhambat atau terpendam dalam proses pembudayaan.

Kreativitas dalam berfikir sangat mempengaruhi proses belajar. Seperti dikemukakan di muka bahwa belajar diawali dari proses ingin tahu. Ketika seseorang mempunyai masalah dan ingin menyelesaikannya, la akan menggunakan pikirannya untuk melihat fakta -fakta apa saja yang terjadi di sekitarnya yang berhubungan dengan masalah tersebut. Kemudian la menghubungkan fakta-fakta yang ada lalu berfikir mencari alternatif penyelesaian sehingga nantinya didapatkan penyelesaian yang diinginkan.

Dalam proses pembelajaran, Nursisto (2000: 5) menyatakan, “... Baik para ahli psikologi maupun guru atau dosen telah menyadari bahwa siswa atau mahasiswa bukan semata-mata penerima informasi. Mereka merupakan insan yang kemampuan kreatifnya harus dikembangkan sepenuhnya melalui proses belajar mengajar". Oleh karena itu, khususnya di kelas, peran guru sangat penting dalam mengembangkan kreativitas siswa agar mereka mempunyai bekal masa depan yang lebih cerah.

Galligan (2006: 20-21) menyatakan bahwa kreativitas itu penting dalam semua aspek pembaharuan dan kemajuan budaya, memerlukan imajinasi, disiplin dan dukungan. Mihaly Csikszentmihalyi, profesor dan mantan Kepala Jurusan Psikologi di Universitas Chicago, mengatakan kreativitas menyediakan daya dorong untuk setiap tindakan, ide, atau produk yang mengubah keberadaan domain (atau disiplin) ke dalam sebuah entitas baru. Dalam susunan ini, kreativitas dalam semua bidang menggunakan sebuah sistem yang terbentuk dari tiga elemen: suatu budaya yang memuat aturan-aturan simbolik, seseorang yang membawa hal baru ke dalam domain simbolik, dan suatu bidang keahlian yang mengenali dan mengesahkan pembaharuan tersebut.

Enny Semiawan, S. Munandar, CU. Munandar (1984: 9) menyatakan bahwa kreativitas adalah kemampuan untuk membuat kombinasi-kombinasi baru, atau melihat hubungan-hubungan baru antar unsur, data, atau hal-hal yang sudah ada sebelumnya. Dari pengertian di atas, kreativitas seakan hanya tertuju pada suatu produk dari hasil pemikiran atau perilaku manusia. Namun sebenarnya kreativitas dapat pula dilihat sebagai proses dan mungkin inilah yang lebih esensial dan perlu dibina pada siswa sejak dini untuk bersibuk diri secara kreatif. 
Lebih lanjut Enny Semiawan et al menyatakan bahwa kreativitas sebagai suatu proses memikirkan berbagai gagasan dalam menghadapi suatu masalah, sebagai proses "bermain" dengan gagasan-gagasan atau unsur-unsur dalam pikiran yang merupakan keasyikan dan penuh tantangan bagi siswa yang kreatif. Bagi pendidikan, yang terpenting bukanlah apa yang dihasilkan dari proses tersebut, melainkan keasyikan dan kesenangan siswa terlibat dalam proses ini sehingga minat dan sikap siswa untuk terlibat dalam kegiatan kreatif harus senantiasa dirangsang dan dipupuk.

Penggunaan masalah nyata (context problem) sangat signifikan dalam PMR. Berbeda dengan pembelajaran tradisional, yang menggunakan pendekatan mekanistik memuat masalah-masalah matematika secara formal (naked problems). Jika menggunakan masalah nyata, dalam pendekatan mekanistik sering digunakan sebagai penyimpulan dari proses belajar. Fungsi masalah nyata hanya sebagai materi aplikasi (penerapan) pemecahan masalah nyata dan menerapkan apa yang telah dipelajari sebelumnya dalam situasi yang terbatas. Dalam PMR, masalah nyata berfungsi sebagai sumber dari proses belajar masalah nyata dan situasi nyata, keduanya digunakan untuk menunjukkan dan menerapkan konsepkonsep matematika.

Ketika siswa mengerjakan masalah-masalah nyata mereka dapat mengembangkan ide-ide/konsep-konsep matematika dan pemahamanya, mereka mengembangkan strategi yang mengarah (dekat) dengan konteks. Kemudian aspek-aspek dari situasi nyata tersebut dapat menjadi lebih umum, artinya model atau strategi tersebut dapat digunakan untuk memecahkan masalah lain. Bahkan model tersebut memberikan akses siswa menuju pengetahuan matematika yang formal. Untuk menjembatani antara tingkat informal dan formal tersebut, model/strategi harus ditingkatkan dari "model of" menjadi "model for". Perbedaan lain dari PMR dan pendekatan tradisional adalah pendekatan tradisional berfokus pada bagian kecil materi dan siswa diberikan prosedur yang tetap untuk menyelesaikan latihan dan sering individual. Pada PMR, pembelajaran lebih luas (kompleks) dan konsepkonsepnya bermakna. Siswa diperlakukan sebagai partisipan yang aktif dalam pembelajaran sehingga dapat mengembangkan ide-ide matematika.

Sementara itu dalam PMRI soal-soal yang digunakan adalah soal-soal yang berkonteks sebagai titik awal bagi siswa dalam mengembangkan pengertian matematika dan sekaligus menggunakan konteks tersebut sebagai sumber aplikasi matematika.

Menurut de Lange (1987, dalam Zulkardi) ada empat macam masalah konteks atau situasi, yaitu:

1) Personal Siswa

Situasi yang berkaitan dengan kehidupan sehari-hari siswa baik di rumah dengan keluarga, dengan teman sepermainan, teman sekelas dan kesenangannya.

2) Sekolah / Akademik

Situasi yang berkaitan dengan kehidupan akademik di sekolah, di ruang kelas, dan kegiatan-kegiatan yang terkait dengan proses pembelajaran.

3) Masyarakat / Publik

Situasi yang terkait dengan kehidupan dan aktivitas masyarakat sekitar dimana siswa tersebut tinggal.

4) Saintifik / Matematik

Situasi yang berkaitan dengan fenomena dan substansi secara saintifik atau berkaitan dengan matematika itu sendiri. 
Tujuan penggunaan konteks adalah untuk menopang terlaksananya proses guided reinvention (pembentukan model, konsep, aplikasi, \& mempraktekkan skill tertentu). Selain itu, penggunaan konteks dapat memudahkan siswa untuk mengenali masalah sebelum memecahkannya. Konteks dapat dimunculkan tidak harus pada awal pembelajaran tetapi juga pada tengah proses pembelajaran, dan pada saat asesmen atau penilaian.

Dalam PMR, de Lange (1987, dalam Zulkardi) mengelompokkan soal-soal kontekstual ke dalam tiga bagian, yaitu:

1) Tidak ada konteks sama sekali

Dalam kelompok ini, kebanyakan soal-soal yang tidak menggunakan konteks sama sekali, langsung dalam bentuk formal matematika. Sebagai contoh: Tentukan akar-akar suatu Persamaan Kuadrat $x^{2}-5 x+6=0$; atau gambarlah grafik fungsi $y=\sin x$.

2) Konteks Dress-up (kamuflase)

Pada kelompok ini, soal-soal biasa diubah menggunakan bahasa cerita sehingga terasa bahwa soal tersebut memiliki konteks. Sebagai contoh soal sistem persamaan linear dengan dua variabel dimana variabel $x$ dan $y$-nya diganti dengan nama barang belanjaan buku dan pensil. Misal : $2 x+y=3$ dan $x+3 y=4$, berapakah nilai $x$ dan y?. Soal ini diubah atau 'dibajui' menjadi 2 pensil dengan satu buku sama dengan tiga satuan dan satu pensil dengan tiga buku sama dengan 4 satuan. Berapa satuankah harga pensil dan buku? Disini terlihat aplikasi hanya kamuflase tetapi tidak bermakna karena kurang fit dengan harga pensil dan buku sebenarnya di toko buku.

3) Konteks yang relevan dengan konsep

Disini, soal-soal betul-betul memiliki konteks yang relevan dengan konsep matematika yang sedang dipelajari. Beberapa contoh ditunjukkan pada bagian akhir makalah ini.

Selain itu, kesulitan soal kontekstual matematika bagi siswa dibagi ke dalam tiga level, yaitu:

a. Level I: Mudah - Reproduksi, definisi, prosedur standar, fakta.

Pada level ini, diperlukan hanya satu konsep matematika. Sebagai contoh adalah:

Gambarkan grafik $y=x$; tentukanlah nilai $x$ pada $x+3=9-3 x$.

b. Level II: Sedang - Kombinasi, Integrasi, Koneksi.

Soal pada level ini membutuhkan paling tidak dua konsep matematika. Type soalnya cenderung merupakan suatu pemecahan masalah atau problem solving. Contoh sederhana, yaitu soal yang menggunakan photo anak-anak SD sedang berbaris secara simetris. Konsep simetris digabung dengan trik pertanyaan yang menggunakan gambar yang sebagian dihilangkan (sebagain barisan laki-laki tidak kelihatan). Yang menarik adalah ada seorang anak yang berada di luar barisan yang tentunya harus dihitung.

c. Level III: Sulit - Matematisasi, reasoning, generalisasi, modeling.

Konsep matematika yang dibutuhkan untuk menjawab soal pada level ini sama dengan pada level 2. Hanya, pada level ini soal-soalnya mengarah kepada generalisasi dan modeling. Sebagai contoh, soal pada situasi personal: $A$ dan $B$ teman sebangku. Jarak rumah A ke Sekolah $3 \mathrm{~km}$ dan jarak rumah B ke Sekolah $5 \mathrm{~km}$. Berapakah jarak rumah mereka?

Persoalan tersebut merupakan soal level ini dimana jawaban akhir dan komplit dari soal tersebut adalah berbentuk tempat kedudukan titik-titik antara dua lingkaran yang berjari-jari 3 dan $5 \mathrm{~km}$ yang kalau di sketsa, gambarnya berbentuk kue donat. Bila dikaitkan 
dengan ketiga level kesulitan soal matematika tersebut, maka fungsi konteks dalam matematika adalah:

1) Pada level ke-tiga: konteks berfungsi sebagai karakteristik dari proses matematisasi;

2) Pada level ke-dua: konteks berperan sebagai alat untuk mengorganisasi dan menstruktur dan menyelesaikan suatu masalah realitas; serta

3) Pada level pertama: tidak ada konteks atau jika ada maka hanya kamuflase, operasi matematika yang di tambahi konteks.

Secara umum dalam PMR, konteks berguna untuk pembentukan konsep: akses dan motivasi terhadap matematika, pembentukan model, menyediakan alat untuk berfikir menggunakan prosedur, notasi, gambar dan aturan, realitas sebagai sumber dan domain aplikasi, dan latihan kemampuan spesifik di situasi-situasi tertentu (Van Reeuwijk 1995, dalam Zulkardi).

\section{METODE PENELITIAN}

Penelitian ini merupakan penelitian kualitatif deskriptif. Dalam penelitian ini, deskripsi yang dimaksud adalah mempelajari secara mendalam bagaimana perilaku siswa terkait kreativitas siswa dalam memecahkan masalah matematika materi pola bilangan dengan Pendekatan Matematika Realistik (PMR). Instrumen dalam penelitian ini adalah peneliti sendiri. Dalah hal ini, peneliti mencari dan mengumpulkan data siswa terkait dengan kreativitas matematika dengan menggunakan instrumen bantu berupa soal pemecahan masalah.

Data dalam penelitian ini adalah kreativitas siswa kelas VII MTs yang hasil pengerjaan siswa dalam soal pemecahan masalah matematika. Data dikumpulkan dengan metode tes. Validitas data dalam penelitian ini dilakukan dengan meningkatkan ketekunan dan triangulasi waktu yang mengacu pendapat Sugiyono (2010: 365). Adapun teknik analisis data dilakukan dengan reduksi data dilakukan dengan cara memilih hasil pengerjaan siswa. Hasil reduksi yang telah dipaparkan, kemudian dipaparkan dalam bentuk analisis.

Data dalam penelitian kualitatif dinyatakan valid apabila tidak ada perbedaan antara yang dilaporkan oleh peneliti dengan apa yang sesungguhnya terjadi dengan objek yang diteliti (Sugiyono, 2011: 365). Dalam penelitian kualitatif kebenaran realitas data tidak bersifat tunggal, tetapi jamak dan tergantung kepada kemampuan peneliti dalam mengkonstruksi fenomena yang diamati. Uji keabsahan dalam penelitian yang akan dilakukan dengan meningkatkan ketekunan dan triangulasi waktu

\section{HASIL PENELITIAN DAN PEMBAHASAN}

Proses pembelajaran atau kegiatan pembelajaran yang dilakukan terhadap materi pola bilangan dengan pendekatan PMR selengkapnya sebagai berikut:

1. Kegiatan Pembelajaran

Adapun kegiatan pembelajaran yang dilakukan adalah sebagai berikut:

a. Guru membagi banyak siswa menjadi 8 kelompok, masing-masing kelompok terdiri dari 5 orang dengan 1 orang sebagai ketua atau juru bicara.

b. Guru menuliskan persoalan berupa konteks (semua kelompok dengan permasalahan/konteks yang sama) yang akan dipecahkan, yaitu sebagai berikut:

Ada 8 orang dalam suatu pesta, setiap tamu berjabat tangan dengan setiap tamu yang lain. Berapa banyak semua jabat tangan yang terjadi? 
Untuk satu jam pertama guru meminta siswa atau masing-masing kelompok untuk mencari penyelesaian soal dengan metode/cara masing-masing. Guru memberikan arahan beberapa alternatif metode/cara penyelesaian kepada siswa. Hal ini dilakukan dengan cara mengarahkan aktivitas siswa, menggunakan gambar, dan tabel.

\section{Aktivitas siswa:}

Pada umumnya siswa terlihat antusias memberikan ide-ide dan berdiskusi apa yang akan dilakukan dalam mengaplikasikan maksud dari soal dalam suatu aktivitas atau praktik nyata. Masing-masing kelompok mencoba mempraktikkan dengan berjabat tangan langsung antar siswa pada kelompok masing-masing. Siswa mulai menyadari bahwa angota kelompoknya hanya 5 orang, sedangkan yang akan dihitung terdiri dari 8 orang. Selanjutnya kreativitas mulai muncul diantaranya:

1. menggabungkan kelompok mereka dengan kelompok lain sehingga cukup 8 orang (penulis mencoba membatasi bahwa coba dahulu hanya dengan banyak anggota masing masing kelompok saja). Selanjutnya siswa mulai mencoba lagi menghitung dengan 2 orang berjabat tangan, 3 orang, 4 orang, dan 5 orang, lalu menuliskan banyak jabat tangan yang terjadi. Pada umumnya hasil jawaban siswa adalah sebagai berikut:

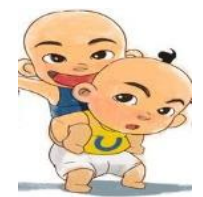

2 Orang = 1 Jabat tangan

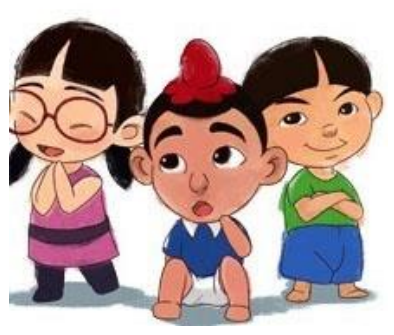

3 Orang $=3$ Jabat tangan

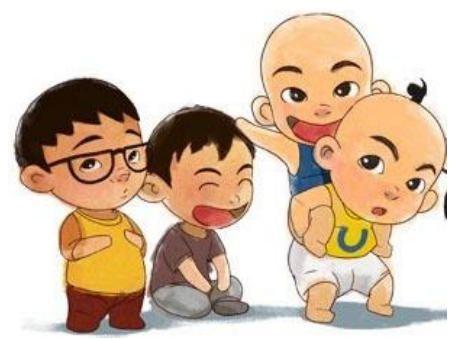

\begin{tabular}{|l|l|l|}
\hline 1 & Upin & Ipin \\
\hline 2 & Upin & Ikhsan \\
\hline 3 & Upin & Fizi \\
\hline 4 & Ipin & Ikhsan \\
\hline 5 & Ipin & Fizi \\
\hline 6 & Ikhsan & Fizi \\
\hline
\end{tabular}

4 Orang $=6$ Jabat tangan

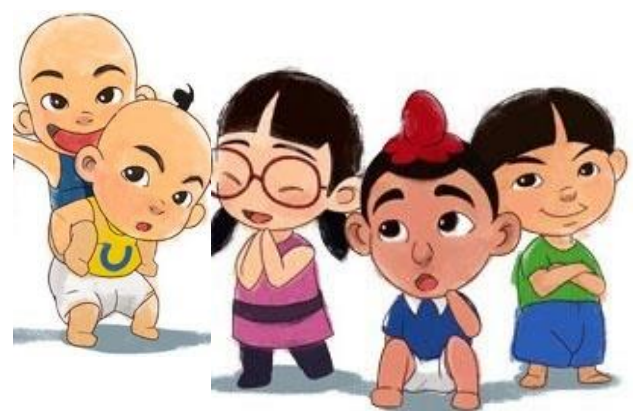

\begin{tabular}{|l|l|l|}
\hline 1 & Upin & Ipin \\
\hline 2 & Upin & Mei-mei \\
\hline 3 & Upin & Jarjit \\
\hline 4 & Upin & Mail \\
\hline 5 & Ipin & Mei-mei \\
\hline 6 & Ipin & Jarjit \\
\hline 7 & Ipin & Mail \\
\hline 8 & Mei-mei & Jarjit \\
\hline
\end{tabular}




\section{Orang $=10$ Jabat tangan}

Guru (penulis) mencoba memberi ilustrasi bahwa aktivitas praktik jabat tangan dapat diganti dengan gambar titik-titik (pengganti orang) lalu hitung banyak garis yang menghubungkan masing-masing titik sebagai pengganti aktivitas jabat tangan. Selanjutnya semua kelompok mencoba, dan hasil hitungannya sama dengan banyak garis yang terbentuk.

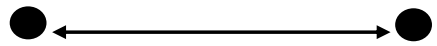

1 garis

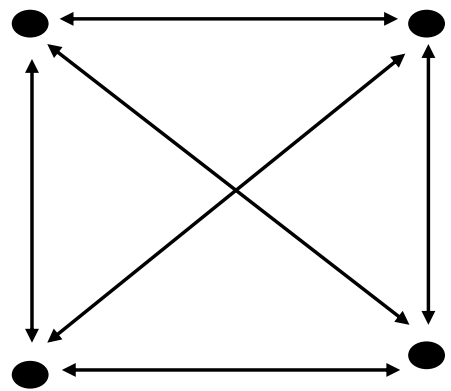

6 garis

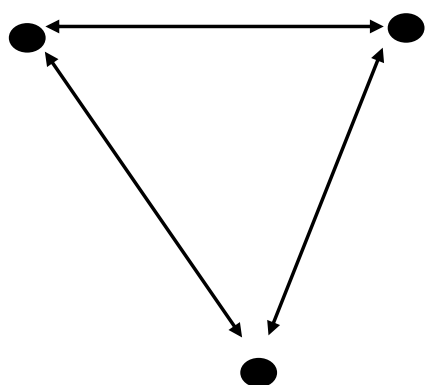

3 garis

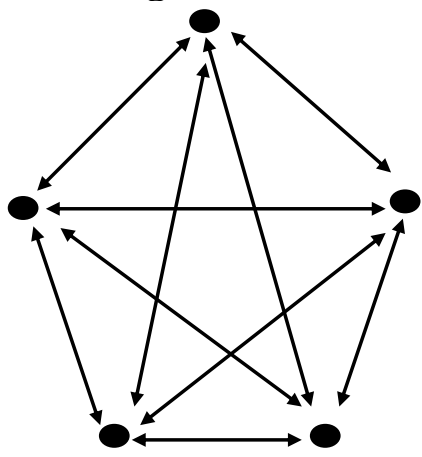

10 garis

Gambar 1. Pola Jabatangan

Selanjutnya, siswa memulai lagi dengan menghitung banyak jabat tangan dengan mengambil sampai dengan 8 titik dan diperoleh 28 jabat tangan.

2. Ada juga beberapa kelompok yang mencoba dengan mengkaitkan bilangan-bilangan hasil, sehingga dengan sedikit bimbingan penulis diperoleh hasil yang sama dengan kelompok yang lain, yaitu: 
Tabel 1: Tabulasi Pengerjaan Siswa

\begin{tabular}{|c|c|c|c|c|c|c|c|}
\hline Banyak Tamu & 2 & 3 & 4 & 5 & 6 & 7 & 8 \\
\hline Banyak Jabat Tangan & 1 & 3 & 6 & 10 & $?$ & $?$ & $?$ \\
\hline
\end{tabular}

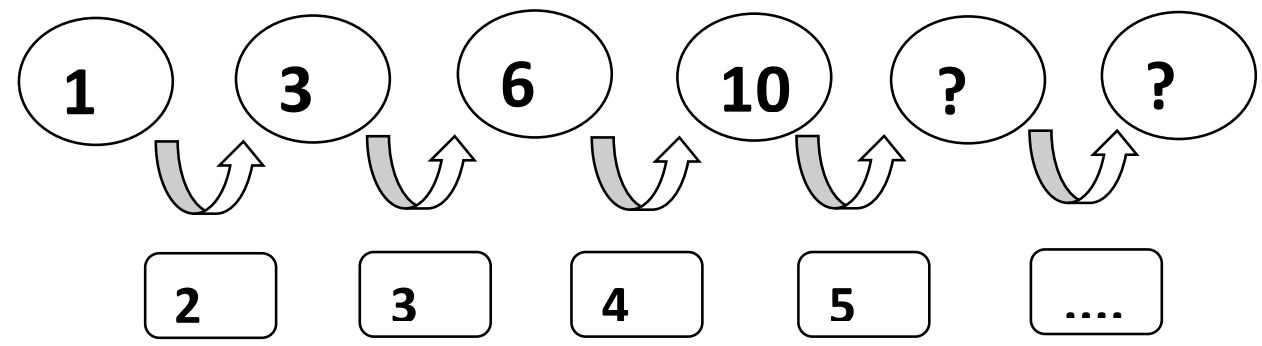

Gambar 2. Ilustrasi Pengerjaan Siswa

Sehingga:

$$
\begin{aligned}
10+5 & =15 \\
15+6 & =21 \\
21+7 & =28
\end{aligned}
$$

Selanjutnya peneliti mencoba mengarahkan siswa untuk mencari pola dari hasil-hasil yang diperoleh. Sehingga dengan sedikit bimbingan dari penulis juga pada umumnya dapat membuat pola sebagai berikut:

Untuk 2 orang/tamu:

Untuk 3 orang/tamu:

Untuk 4 orang/tamu:

Untuk 5 orang/tamu:

$$
\begin{array}{lll}
1 & & \\
3 & = & 1+2 \\
6 & = & 1+2+3 \\
10 & = & 1+2+3+4
\end{array}
$$

Untuk 8 orang/tamu:

$28=1+2+3+4+5+6+7$

Selanjutnya, pada satu jam yang kedua, guru meminta beberapa kelompok dengan perwakilan masing-masing untuk menentukan jawaban dari persoalan dengan memberikan alasannya.

Pada akhirnya siswa diminta untuk menyimpulkan pendekatan yang digunakan dalam kaitan dengan rumus pola bilangan / deret bilangan, bila diperlukan dengan arahan/bimbingan guru. Selanjutnya bila yang ditanya, berapa untuk $n$ tamu?

Berarti: $\quad 1+2+3+4+\ldots+(n-1)$

\section{SIMPULAN DAN SARAN}

Berdasarkan pembahasan hasil penelitian disimpulkan bahwa:

1. Mempelajari pola bilangan lebih menarik dan mudah jika menggunakan pendekatan matematika realistik.

2. Pembelajaran matematika realistik memperkenalkan masalah yang bersifat aplikatif dalam kehidupan sehari-hari sehingga pembelajaran akan lebih bermakna.

3. Pembelajaran matematika realistik menekankan pada penanaman konsep pemahaman, kreativitas siswa dan poses nalar dalam matematika.

Mengingat peran pendidikan matematika sangat penting bagi pendidikan dan kehidupan siswa dan berdasarkan simpulan penelitian di atas dapat dikemukakan saran sebagai berikut: 
1. Hendaknya guru melakukan pembiasaan untuk memberikan soal-soal tantangan yang menuntut kemampuan bernalar. Soal tantangan dapat berupa soal dengan penyelesaiannya yang tidak menggunakan prosedur rutin dan soal yang menuntut kemampuan menyampaikan ide atau gagasan siswa;

2. Hendaknya siswa mulai sejak dini diperkenalkan masalah yang bersifat aplikatif dalam kehidupan sehari-hari agar pembelajaran lebih bermakna.

3. Guru hendaknya mampu memberikan konsep pemahaman dan pengembangan kreativitas siswa dalam pembelajaran matematika dengan menggunakan beberapa macam pendekatan yang relevan bersifat riil dan aplikatif dalam kehidupan.

4. Menanamkan kesan yang baik dan positif pada siswa tentang matematika yang menyenangkan dan menarik.

5. Bagi para insan pendidikan hendaknya lebih sering melakukan penelitian-penelitian pendidikan matematika sehingga problematika pendidikan matematika di Indonesia dapat terungkap.

\section{DAFTAR PUSTAKA}

Enny Semiawan, S. M. (1984). Memupuk Bakat dan Kreativitas Siswa Sekolah Menengah. Jakarta: PT. Gramedia.

Galligan, A. (2006). Art, Culture and The National Agenda. The Journal of Creativity, Culture, Educational, and The Workforce. Vol.28, No.6, 20-21.

Hadi, S. (2003). Paradigma Baru Pendidikan Matematika. Rantau Kabupaten Tapin, Kalimantan Selatan: Forum Komunikasi Sekolah Inovasi Kalimantan Selatan.

Hadi, S. (2013). Menjadikan Pelajaran Matematika Lebih Bermakna bagi Siswa. Seminar Nasional Pendidikan Matematika. Yogyakarta: Universitas Sanata Dharma.

Marpaung, Y. (2007). Matematika Horizontal dan Matematisasi Vertikal. Jurnal Pendidikan Matematika PPS Unsri, Volume 1, No.1, 1-20.

Max A Sobel, E. M. (2004). Mengajar Matematika: Sebuah Buku Sumber Alat Peraga, Aktivitas, dan Strategi -Ed.3 . Jakarta: Erlangga.

Munandar, U. (2004). Memupuk Bakat dan Kreativitas Siswa Sekolah Menengah. Jakarta: PT. Gramedia.

Noormandiri. (2004). Matematika SMA untuk Kelas XII IImu Alam. Jakarta: Erlangga.

Nursisto. (2000). Kiat Menggali Kreativitas. Yogyakarta: Mitra Gamawidya.

Purwoto. (1996). Strategi Belajar Mengajar Matematika. Surakarta: Universitas Sebelas Maret Press. 